Gosstroi (State Building Committee) with its Collegium (sub-committee for effective guidance and decisions on present-day problems), Functional Directorates (materialtechnical supply, economics, finance, mechanization, personnel, management and foreign relations) and Branch Directorates (embracing, among other functions, agricultural, chemical and oil industries construction).

\section{The Mauritius Institute}

THe Mauritius Institute was founded in 1880, "for the purpose of promoting the general study and cultivation of various Branches and Departments of Arts, Seience, Literature and Philosophy, and for the instruction and recreation of the people". The foundation stone was laid on November 23, 1880, by the Governor, Sir George Bowen, and on December 3, 1884, Sir John Pope Hennesy, then Governor, formally opened the building to the public on the occasion of the Intercolonial Exhibition. The following year the Natural History Museum, known as the Desjardins Museum, which was then managed by the Royal Society of Arts and Sciences of Mauritius (founded 1829), was transferred from the Royal College of Port Louis to the newly erected Mauritius Institute, together with the library of the Royal Socioty of Arts and Sciences. The Public Library was opened later, in 1902, when the rich collection of books, consisting of some 9,000 volumes, was bequeathed to the Colony by an eminent Mauritian lawyer and politician, Sir Virgile Naz (1825-1901). The Mauritius Institute is now composed of : a public library which includes lending and reference sections; a public museum, composed of natural history, arts and historical sections; the historical museum near Mahebourg; and five learned societies, which use the premises of the Institute for their meetings and for their library. The work of the Institute during 1963 is described in the annual report (Pp. 15. Port Louis: Government Printer, 1963. Rs. 1).

\section{Computers in Medicine and Biology}

The July 1964 part of the Annals of the New York Academy of Sciences (115, Art. 2. Pp. 543-1140) contains a collection of papers on the general topic: "Computers in Medicine and Biology". The contents are divided into seven principal subjects. The first part discusses digital and analogue computers and their relation to biological and medical application, and deals also with the way in which a medical data-processing centre should be organized; the second is mainly concerned with the technology of the computers themselves and describes a number of general and special purpose devices which are particularly appropriate for medical use. The last four sections of the book contain papers on computer applications in specific branches of medicine and biology; neurophysiology, psychiatry and psychophysiology, general biology and cardiology. The collection is a valuable addition to the relatively sparse literature in this field. It is well written and modern in flavour, and everyone interested either in computers or in their application in biology will wish to read it.

\section{The National Central Library}

THE forty-eighth annual report of the Executive Committee of the National Central Library covers the year ended March 31, 1964 (Pp. 24. London: The National Central Library, 1964). Requests for loans reached 107,742 compared with 98,690 in $1962-63$ and of these 78.75 por cent were satisfied; some 78 per cent of requests made by the Library abroad on behalf of British libraries were also satisfied. Total loans made by overseas libraries increased from 3,443 to 3,739 -British loans abroad increasing from 2,686 to 3,488 , while the number of photographic reproductions supplied increased from 603 to 630 for overseas libraries and from 936 to 1,532 for British libraries. Wost Germany and France were the chief lenders to British libraries, West Germany being the principal borrower, followed by Hungary, Italy, Denmark, Poland and the U.S.S.R. University libraries supplied 21,088 loans at the request of the National Central Library and 18,049 loans were made by the Library or through its agency to University libraries. Compietion of the new building is not now expected before May 19, 1965 , and meanwhile the Library has been reorganized on the basis of two divisions, one dealing with inter-lending, the other with the acquisition of books and periodicals by purchase and donation and dealing with all cataloguing and the completion of the Library's master union catalogue. Work has proceeded on the preparation of the British union catalogue of periodicals on a quarterly basis with annual and quinquennial accumulations as from March 1964, and it has been agreed with the Council of the World List of Scientific Periodicals that the two publications should be merged in future. Each annual accumulation will be published in two parts: a general volume containing all periodicals listed in the previous four quarterly parts, and a scientific volume containing periodicals in science and technology. Representations were made in connexion with the Public Libraries and Museums Bill against the proposal to reduce the Government grant to the Library by 50 per cent, and the Act now makes no mention of the State grant to the Library in relation to its total income. The grant for the year ending March 31, 1964, was $£ 95,000$ compared with $£ 82,500$ for the previous year. A survey of loan requests during the six months January-June 1964 was commenced, and it is hoped that the results will be of service to the Committee on Library and to the Department of Education and Science.

\section{Micromechanics}

Several microprocessing methods have been developed for use in microelectronics. These include electron beam and more recently laser beam drilling, both of which are thermal processes, but with different effects. An interesting comparison of the two methods of drilling is described by S. Namba and P. H. Kim in the Japanese Journal of Applied Physics (3, 536, September 1964). The electron beam machine consists of two chambers, both at a pressure of $10^{-5} \mathrm{~mm} \mathrm{Hg}$. The electron beam chamber contains the electron gun, the electrostatic deflexion plates and the focusing magnetic lenses. The beam is emittod from a tungsten hairpin filament, and the location of the beam spot on the workpiece and the intensity of the beam can be controlled either by using a television system to monitor the deflexion and intensity of the beam, or by moving the workpiece by means of a digital control system. The laser machine consists of a ruby rod $15 \mathrm{~cm}$ long, supported inside two helical xenon flash tubes enclosed within an aluminium cylinder, and cooled by compressed air. The workpiece is viewed by means of a built-in mieroscope at times between the laser flashes. The maximum input energy is 12,500 joules, and the laser beam is focused on to the workpiece by a lens. The workpiece carriage can be moved in three mutually perpendicular directions independently. Photographs of etched cross-sections of holes drilled by both beams in various metals, including $\mathrm{Ta}, \mathrm{Nb}, \mathrm{Ni}, \mathrm{Mo}, \mathrm{Zr}$ and stainless steel, are shown and discussed. Stainless steel was the easiest to process. Quartz, which is transparent to light, cannot be drilled by the laser boam. The minimum spot attainable with the electron beam was about $40 \mu$, in accordance with the theoretical value of several tons of microns, and from 0.3 to $0.6 \mathrm{~mm}$ for the laser beam. In thermal processing, drilled holes are generally tapered if the absorbed energy is not so large as to evaporate the material of the whole spot area at once. The holes are larger for the laser beam than for the electron beam, probably because the laser beam is not perfectly parallel and the melt is carried away over a larger area. The laser beam holes are also rarely round-shaped, usually spiky. Though the laser beam processing is simpler and easier to 